\title{
The Perspective Of Criminal Law And Human Rights Against Euthanasia
}

\author{
Zulkarnain $^{1}$ \\ \{zulkarnain.policia@gmail.com ${ }^{1}$ \} \\ Universitas Lampung, Lampung, Indonesia ${ }^{1}$
}

\begin{abstract}
Euthanasia is an effort carried out to help a person accelerate his death easily due to an inability to endure long suffering and no more hope for life or cure. Euthanasia is closely related to various aspects such as legal, moral, religious and Human Rights (HR) aspects. The issue discussed in this journal is how the perspective of criminal law and human rights against euthanasia. The method used in this research is normative juridical by using secondary data, books, documents, and scientific journals. The results of this journal study concluded the perspective of criminal lawprohibit and state that euthanasia mis a form of crime. However, IDI Circular Letter No. 702 / PB / H2 / 09/2004 also provides an exception allowing euthanasia on condition that the court allows. While the perspective of Human Rights (HR) towards euthanasia is divided into pros and cons. According to pro euthanasia is part of the right to self determination. Meanwhile, according to the counter euthanasia is considered a violation of Human Rights (HR) because the existence of the right to life does not mean that a human being has the right to die which is basically an absolute right of God. The author provides advice to government should make special rules regarding euthanasia by observing and upholding human rights.
\end{abstract}

Keywords : euthanasia, criminal law, human rights

\section{Introduction}

Science and technology are growing rapidly, including in the field of health sciences or called modern health sciences. The development of science and technology in the field of health sciences has a positive impact marked by the discovery and development of equipment and drugs that are more effective in diagnosing a disease, treating patients and lengthening the patient's age in a certain time. However, although health science has developed rapidly, in reality there are also many new diseases that have emerged and were discovered and there are also some patients who have certain diseases and are difficult to cure.[1]

Another result of the development of science and technology in the health field, death is not always something that comes suddenly. Death can be made into something definite and can be determined the time and place. Euthanasia is an effort carried out to assist a person in accelerating his death easily due to the inability to endure long suffering and there is no hope for life or healing.[2]

In addition, the burden of costs borne by the patient's family for treatment is also often the reason for someone or the patient's family to ask for euthanasia. For example, on October 22, 2004, Hasan Kesuma, husband of Agian Isna Nauli, submitted a request for euthania to his wife on the grounds of ending his wife's suffering and also the inability to bear the burden of care costs for having a postpartum brain injury, even though the court rejected his application. 
Euthanasia is an act of killing that can be done legally. Which is very closely related to various aspects such as law, morals, religion, and Human Rights (HAM).[3] In principle, death will surely be experienced by every human being but in the case of euthanasia, whether death is a Human Rights (HAM) and what is the legal basis and limits in carrying out euthanasia actions. This problem is still a debate by the world, including Indonesia. Based on the explanation that has been presented, this study tries to see how the perspective of criminal law and Human Rights (HAM) towards euthanasia.

\section{Research Method}

Legal research conducted is a normative legal research with a normative juridical approach which focuses on the use of secondary data research materials or materials supported by library data using secondary data, namely trying to find books, concepts, theories. and expert opinion and findings that are closely related to the subject matter to be studied.[4] The steps and / or process of writing a literature review follows several ways, namely defining the topic, writing a specific question to provide research direction, conducting research, analysis and evaluation and writing a literature review. Research activities in the literature review include activities to find relevant sources, reading and recording main thoughts, conclusions, strengths, and weaknesses of the study.

\section{Discussion}

\subsection{Criminal Law Perspective on Euthanasia}

Euthanasia is etymologically derived from Greek eu which means good and thanatos which means to die or die in a calm and happy state. Euthanasia is assistance given to someone to die peacefully at their own request. This understanding was later expanded and as "ending human life without getting sick with the aim of stopping severe physical suffering and as a way of dealing with victims who experience illness that cannot be cured anymore". This means that the act of euthanasia is intentional, whether by active or passive action, ending the life of others at the request of the person concerned. It is this help with others that distinguishes euthanasia from suicide. In suicide one does not use another person to obtain his death.[5]

In the world of medicine contained in the explanation and guidelines for the implementation of the Indonesian Medical Ethics Code, euthanasia is:[6]

1) Move into the afterlife calmly and safely without suffering and for those who believe in the name of Allah in the lips;

2) Life time will end (sakaratul maul) the patient's suffering is alleviated by giving a sedative;

3) End the patient's suffering and life intentionally at the request of the patient himself and his family.

From the above definitions, it can be concluded that the elements of euthanasia are as follows:[5]

1) Do something or don't do something;

2) Terminate life, accelerate death, or not prolong the patient's life;

3) The patient has an illness that is difficult to cure;

4) At or without the request of the patient and or his family;

5) For the sake of the patient and or his family. 
Euthanasia can be divided into 4 types as follows:[7]

a) Active euthanasia.

Active euthanasia occurs when a doctor or other health worker deliberately takes an action

to end or shorten a patient's life. Active euthanasia is divided into two groups, namely:[8]

a. Euthanasia is active right away.

that is, it is carried out by carrying out medical actions which are expected to immediately end a patient's life such as, giving cyanide tablets or lethal injection of substances.

b. Indirect active euthanasia.

That is done by taking medical measures that can end the patient's life such as, depriving oxygen.

c. Passive Euthanasia.

Passive euthanasia occurs when doctors or other health workers intentionally do not provide any medical assistance to patients who can prolong their lives.

d. Voluntary euthanasia.

Voluntary euthanasia occurs as a result of the patient's own request by refusing medical measures and drugs given to him.

e. Non-voluntary euthanasia

Involuntary euthanasia occurs when the patient is unconscious or unable to make a choice between life and death. The decision was made by someone else who is competent on behalf of the patient (family) or the patient has previously verbally expressed a desire to die. For example, the patient is in a long coma or has severe brain damage.

f. Involuntary euthanasia.

Euthanasia involuntary tThis occurs when the other party ends the patient's life and opposes the patient's original wish statement. For example, the patient wants to continue to survive even in conditions of suffering, the family asks the doctor to end his life. Involuntary euthanasia is almost always considered murder.

When we talk about legal policies regarding euthanasia, in Indonesia there are no specific rules governing them. However, in general in the Criminal Code there are several legal rules relating to this euthanasia problem. This is enforced because euthanasia is a crime against life. These rules include:[9]

1) Article 338 of the Criminal Code

"Anyone who intentionally takes another person's life, is threatened with murder for a maximum of five years in prison."

2) Article 339 of the Criminal Code

"A murder that is followed, accompanied or preceded by a criminal act, which is carried out with a view to preparing or facilitating its implementation, or to free oneself or other participants from the criminal in the case of being caught red-handed, or to ensure possession of goods obtained illegally, is threatened by imprisonment for life or for a specified time, a maximum of twenty years ".

3) Article 340 of the Criminal Code

"Anyone who intentionally and with plans in advance take the life of another person, threatened with murder by a plan, with capital punishment or life imprisonment or for a specified time, a maximum of twenty years"

4) Article 304

"Anyone who deliberately puts or leaves someone in a miserable condition, whereas according to the law that applies to him or because of the agreement he is obliged to give life, care or maintenance to that person, is threatened with a maximum imprisonment of two years and eight months or a maximum fine of four thousand five hundred rupiah " 
5) Article 344

"Anyone who takes the life of another person at the request of that person himself, who is mentioned clearly and solemnly, is sentenced to prison for twelve years".

6) Article 345

"Whoever intentionally encourages another person to commit suicide, helps him in the act or gives him the means for it, is threatened with a maximum prison sentence of four years if that person commits suicide".

7) Article 359

"Anyone who due to his mistake (negligence) causes another person to die, is threatened with a maximum of five years imprisonment or one year imprisonment".

Besides stipulated in the Criminal Code, there are also some rules for doctors in conducting euthanasia including:[3]

1) Circular Letter IDI No. 702 / PB / H2 / 09/2004

Stating that Indonesia as a country based on Pancasila, with the first precept is the Almighty God, it is impossible to accept the action of "active euthanasia".

The precepts of "the Godhead of the One" in the first place of Pancasila indicate that Indonesia is a country that ethically and morally noble recognizes the existence of God. Indonesia recognizes 6 religions namely Islam, Christianity, Catholicism, Hinduism, Buddhism, and Confucianism. None of the six religions allows euthanasia. Birth and death are absolute rights of God. For example in Islam which prohibits euthanasia in one of the verses of the Qur'an, which is Surah Al Maidah (5) verse 32 ".. Whoever kills a human being, not because that person (killed) another person, or not because it makes damage on earth, then it was as if he had killed a whole human. And whoever takes care of the life of a human being, then it is as if he has preserved the lives of all people ... ".

2) Indonesian Medical Ethics Code (KODEKI)

Article 7 letter (d) states:

"Every doctor must always remember the obligation to protect the lives of human beings." In the explanation it is stated that according to religion, state law and medical ethics, a doctor is not allowed if:

a. Miscarriage (abortion provocatus);

b. End the life of a patient who according to science and knowledge is unlikely to recover (euthanasia).

3) If seen in the explanation and implementation guidelines, clearly and firmly outlined a prohibition regarding euthanasia actions. Although often doctors or other health professionals are faced with very poor patient conditions such as cancer in advanced stages with pathetic conditions and in the medical world it is predicted that there is no hope for life, but doctors and other health workers still do not have any right to ending the patient's life even with the good intention of ending the patient's suffering. Doctors and other health workers are only obliged to exert all their abilities to alleviate the suffering of patients.

Based on the values and norms that live in society, euthanasia is also contrary to human values. The human value is contained in the Pancasila (basic state) which is supposed to be the philosophy of life of the nation and the guidelines of the community in acting, as explained:

"As a value, Pancasila contains a must to be implemented. Values are ideas that serve as motivation for all humans' attitudes, behavior, and actions. Since the founding fathers of the nation have explored, discovered and believed the importance of the values of Pancasila, they hope that all Indonesian people who have chosen the freedom to determine their life goals can support the realization of these values. Thus, in order to make these values able to attract 
people's attention, these values need to be formulated in a clear formula as the ideal goal of the nation. These values have been formally formulated and stipulated in the Preamble of the 1945 Constitution and are an ideal goal of Indonesian people. Formally, the values of Pancasila are values that must be accepted, supported and respected by all Indonesian people. The values of Pancasila are outlined in the Preamble of the 1945 Constitution constitute legal and moral ideas which are the hopes and dreams of Indonesian people. The values of Pancasila, as the ideals of all Indonesian people, will be able to attract all Indonesian people to realize them in their attitudes and actions in everyday life.[10]

From the explanation above, legally, euthanasia especially active euthanasia is a form of crime but in criminal theory there are also exceptions to criminal liability. As exemplified above with very poor patient conditions such as cancer in an advanced stage with pathetic conditions and in the medical world it is predicted that there is no hope for life, one way to end the suffering of patients is by performing euthanasia. What is done by the doctor is indeed a form of crime but the doctor in question is not burdened with criminal responsibility or desires and even exemption from punishment by expanding the meaning of article 48 of the Criminal Code due to the influence of force.[1]

The validity of Article 48 of the Criminal Code is enforced by referring to Circular Letter IDI No. 702 / PB / H2 / 09/2004 which also provides an exception to euthanasia on condition that the court allows such action. Permission granted by the court is limited and must be based on meeting medical requirements not for socio-economic reasons. The limitative nature is used to prevent the submission of euthanasia not arbitrarily.

\subsection{Perspectives on Human Rights (HAM) Against Euthanasia}

As a state of law, Indonesia recognizes and upholds Human Rights (HAM). According to the theory of natural rights, Human Rights (HAM) are the rights possessed by all people at all times and in all places as human beings which are the essential rights that a person has had since birth. This right is inherent in everyone and cannot be taken, revoked, deprived, or transferred to others for and by anyone.[11]

Described in Article 1 number 1 of Law Number 39 of 1999 concerning Human Rights (HAM) explains that Human Rights (HAM) is a set of rights inherent in the nature and existence of humans as creatures of God Almighty and is His gift which must be respected, upheld and protected by the state, law, government, and everyone for the sake of respect and protection of human dignity.

If we discuss euthanasia from the aspect of Human Rights (HAM), then it will be very closely related to the right to life which is the fundamental right of every human being. As evidenced by several people in Indonesia who submitted to court wanting euthanasia, this shows that many people feel that they not only have the right to life but also have the right to die. This has been the debate for the pros and cons.[3]

According to the pro, a human has his own right to what will happen to his life. A human has the right to determine his own destiny. The right to self-determination is a right inherent in human beings, in the sense that someone has the right to determine what will or needs to be done on him (his body). Provisions regarding the basic rights of individuals which in this case are related to the right to self-determination are contained in the International Covenant of Civil and Political Rights, namely in Article 1 "Everyone has the right to self-determination".

The presence of euthanasia as a Human Rights (HAM) in the form of the right to die, is considered as a result of the existence of the right to life. Because everyone has the right to life, then everyone also has the right to choose death that is considered pleasing to him. This explains the basic concept of Human Rights (HAM) which focuses on the right to personal freedom 
which is one of the most fundamental rights for everyone because it also involves the right to self-determination (right of self determination).

The right to self-determination is also closely related to the basic rights of the patients listedin Law No. 36 of 2009 concerning Health Article 56 paragraph 1, Patient Protection, namely "Everyone has the right to accept or reject some or all of the relief measures that will be given to him after receiving and understanding information about such actions in full".

However, when viewed in the perspective of Human Rights (HAM) Euthanasia according to the counter-euthanasia people is considered to violate Human Rights (HAM) because it contradicts the right to human life because it is deliberately shortening one's life span. Where the right to life does not mean that a person has the right to die anyway because basically the right to die is an absolute right of God Almighty, God knows when someone dies and God has the right to end human life.[11]

The right to life is normatively protected in Indonesia in the 1945 Constitution of the Republic of Indonesia, namely Article 28A and Article 28 I paragraph 1. The right to life is also protected in Indonesia with the issuance of Law No. 39/1999 concerning Human Rights (HAM) and Law No. 26/2000 concerning the Human Rights Court. According to the General Explanation of Law No. 39/1999, the legal position of the Act is an umbrella of all statutory provisions concerning Human Rights (HAM). Therefore, direct or indirect violations of human rights are subject to criminal, civil and administrative sanctions in accordance with statutory provisions. UU no. 39/1999 specifically regulates: the right to life and the right not to be forcibly removed and / or not to lose a life listed in Article 4, Article 9, and Article 33 paragraph 2.

In addition, there are international rules that have been conventions by Indonesia to protect human rights, namely Law Number 12 of 2005 concerning the International Covenant of Civil and Political Rights (International Covenant on Civil and Political Rights), namely Article 6 "That every human being has the right to life, that this right is protected by law, and that no one can be arbitrarily deprived of his right of life".[12]

Regarding the right to self-determination which is the basis of the pros, these rights are not explained in detail and do not yet have clear boundaries in the International Covenant of Civil and Political Rights (International Covenant on Civil Rights and Political). These rights are mostly internally defined as the right of a nation to choose their own form of state and government. This right is closely related to political interests.

\section{Conclusion}

1) The criminal law perspective against euthanasia, especially active euthanasia conclude that euthanasia is prohibited and mis a form of crime. Although,in Indonesia there is no legal policy that specifically regulates euthanasia, but in general in the Criminal Code there are several legal rules relating to this euthanasia problem including Article 338, Article 339, Article 340, Article 304, Article 344, Article 345, and Article 359 of the Criminal Code. In addition to being regulated in the Criminal Code, there are also some rules for doctors in conducting euthanasia, including inCircular Letter IDI No. 702 / PB / H2 / 09/2004 and Indonesian Medical Ethics Code (KODEKI). However, based on Circular Letter IDI No. 702 / PB / H2 / 09/2004 also gives an exception to the permissibility of euthanasia on condition that the court allows.

2) The Human Rights Perspectives on euthanasia are divided into pros and cons. According to pro-euthanasia is part of the right to self-determination. Meanwhile, according to the 
counter-euthanasia is considered a violation of Human Rights (HAM) because the existence of the right to life does not mean that a person has the right to die, which is basically the right to die is an absolute right of God Almighty.

\section{References}

[1] A. Rada, "EUTHANASIA SEBAGAI KONSEKUENSI KEBUTUHAN SAINS DAN TEKNOLOGI (Suatu Kajian Hukum Islam),” J. Din. Huk., vol. 13, no. 2, pp. 332-343, 2013.

[2] L. Yudaningsih, "Tinjauan Yuridis Euthanasia Dilihat Dari Aspek Hukum Pidana," J. Ilmu Huk. Jambi, vol. 6, no. 1, p. 43316, 2015.

[3] L. Badu, "EUTHANASIA DAN HAK ASASI MANUSIA," J. Craniofac. Surg., vol. 8, no. 2, pp. 146-150, 1997, doi: 10.1097/00001665-199703000-00016.

[4] M. Abdul Kadir, "Hukum Dan Penelitian Hukum.," Bandung PT. Citra Aditya Bakti., vol. 8, no. 1, p. 52, 2015, doi: 10.25041/fiatjustisia.v8no1.283.

[5] D. Rachma, K. Tsani, E. L. Simanjuntak, F. Psikologi, U. Katolik, and W. Mandala, "Sikap terhadap Euthanasia Ditinjau dari Jenjang Pendidikan pada Mahasiswa Fakultas Kedokteran," Toxic. raw kidney-beans, vol. 5, no. 1, pp. 81-92, 1949, doi: 10.1007/BF02153738.

[6] M. D. B. I. Wakiran, D. C. Tomuka, and E. G. Kristanto, "Pendekatan Bioetik Tentang Eutanasia," J. Biomedik, vol. 5, no. 1, 2013, doi: 10.35790/jbm.5.1.2013.2602.

[7] N. Asma, "Euthanasia dan Prospeksi Pengeturannya dalam Hukum Islam dan Hukum Pidana Noor Asma Fakultas Syariah IAIN Sultan Amai Gorontalo Email : nurasmaz82@gmail.com Abstrak Key Word : Euthanasia, Hukum Pidana, Hukum Islam Pendahuluan Pesatnya penemuan teknologi," vol. 2, pp. 167-190, 2018.

[8] A. E. Kusumaningrum, "PERGULATAN HUKUM DAN ETIK TERHADAP EUTHANASIA DI RUMAH SAKIT," J. Spektrum Huk., vol. 15, no. 1, pp. 89-111, 2018.

[9] Y. Muhammad, "PRAKTIK EUTHANASIA PASIF DI INDONESIA MENURUT PANDANGAN HUKUM ISLAM," Director, vol. 15, no. April, pp. 2017-2019, 2018, doi: 10.22201/fq.18708404e.2004.3.66178.

[10] M. Arwani, "TINJAUAN YURIDIS TINDAK PIDANA EUTHANASIA BERDASARKAN HUKUM DARI BEBERAPA NEGARA (INDONESIA-BELANDA- AMERIKA SERIKAT)," J. Chem. Inf. Model., vol. 53, no. 9, pp. 1689-1699, 2013, doi: 10.1017/CBO9781107415324.004.

[11] M. Termorshuizen, "Euthanasia," pp. 45-58, 1992.

[12] Abd. Halim, "EUTHANASIA DALAM PERSPEKTIF MORAL DAN HUKUM.” 